\title{
Brazilian Cerrado Soil Actinobacteria Ecology
}

\author{
Monique Suela Silva, ${ }^{1}$ Alenir Naves Sales, ${ }^{1}$ Karina Teixeira Magalhães-Guedes, ${ }^{1}$ \\ Disney Ribeiro Dias, ${ }^{2}$ and Rosane Freitas Schwan ${ }^{1}$ \\ ${ }^{1}$ Department of Biology, Federal University of Lavras (UFLA), Campus Universitário, 37.200-000 Lavras, MG, Brazil \\ ${ }^{2}$ Department of Food Science, Federal University of Lavras (UFLA), Campus Universitário, 37.200-000 Lavras, MG, Brazil
}

Correspondence should be addressed to Disney Ribeiro Dias; diasdr@dca.ufla.br

Received 15 October 2012; Revised 4 December 2012; Accepted 19 December 2012

Academic Editor: George Tsiamis

Copyright (C) 2013 Monique Suela Silva et al. This is an open access article distributed under the Creative Commons Attribution License, which permits unrestricted use, distribution, and reproduction in any medium, provided the original work is properly cited.

A total of 2152 Actinobacteria strains were isolated from native Cerrado (Brazilian Savannah) soils located in Passos, Luminárias, and Arcos municipalities (Minas Gerais State, Brazil). The soils were characterised for chemical and microbiological analysis. The microbial analysis led to the identification of nine genera (Streptomyces, Arthrobacter, Rhodococcus, Amycolatopsis, Microbacterium, Frankia, Leifsonia, Nakamurella, and Kitasatospora) and 92 distinct species in both seasons studied (rainy and dry). The rainy season produced a high microbial population of all the aforementioned genera. The $\mathrm{pH}$ values of the soil samples from the Passos, Luminárias, and Arcos regions varied from 4.1 to 5.5. There were no significant differences in the concentrations of phosphorus, magnesium, and organic matter in the soils among the studied areas. Samples from the Arcos area contained large amounts of aluminium in the rainy season and both hydrogen and aluminium in the rainy and dry seasons. The Actinobacteria population seemed to be unaffected by the high levels of aluminium in the soil. Studies are being conducted to produce bioactive compounds from Actinobacteria fermentations on different substrates. The present data suggest that the number and diversity of Actinobacteria spp. in tropical soils represent a vast unexplored resource for the biotechnology of bioactives production.

\section{Introduction}

Actinobacteria are a distinct group of bacteria that are widely distributed in nature [1]. Currently [2], Actinobacteria comprise eight groups with 48 genera. Special attention has been given to this bacterial group in biotechnological applications, which are a natural result of their great metabolic diversity [3]. Actinobacteria are the most common source of antibiotics [4] and are a promising source of a wide range of enzymes, enzyme inhibitors, immunomodifiers, and vitamins [5]. In nature, Actinobacteria play an important role in the cycling of organic compounds and have been associated with soil organic matter production, including production of the black pigments called melanin, which are related to soil humic acid [6].

Streptomyces is the most common Actinobacteria genus found in soils and constitutes up to $90 \%$ of the isolates. However, new approaches for the isolation of soil Actinobacteria have revealed that other genera are also present in significant numbers. Many new species have been isolated, and most of the isolates are able to produce novel secondary metabolites [1]. Since the first antibiotic from an Actinobacterium, reported more than 50 years ago [7], more than 4000 new bioactive compounds have been discovered. The search for new species or strains of the Actinobacterium group is still of primary interest to the biotechnology field.

Actinobacteria taxonomy is extremely complex, and classification using only the traditional methods, which are based on morphological and physiological characteristics, has led to very heterogeneous suprageneric groups. Recently, three main approaches have been suggested to identify species of Actinobacteria: chemotaxonomy (differentiation of species by chemical composition), numerical taxonomy (differentiation of species by phenotypic similarity number), and molecular systematics (use of DNA study to the species differentiation). A combination of three techniques becomes more complete [1].

Brazilian Cerrado soils have an enormous biodiversity potential. Some of these soils have been described as habitats with high biological activity but have not been extensively 


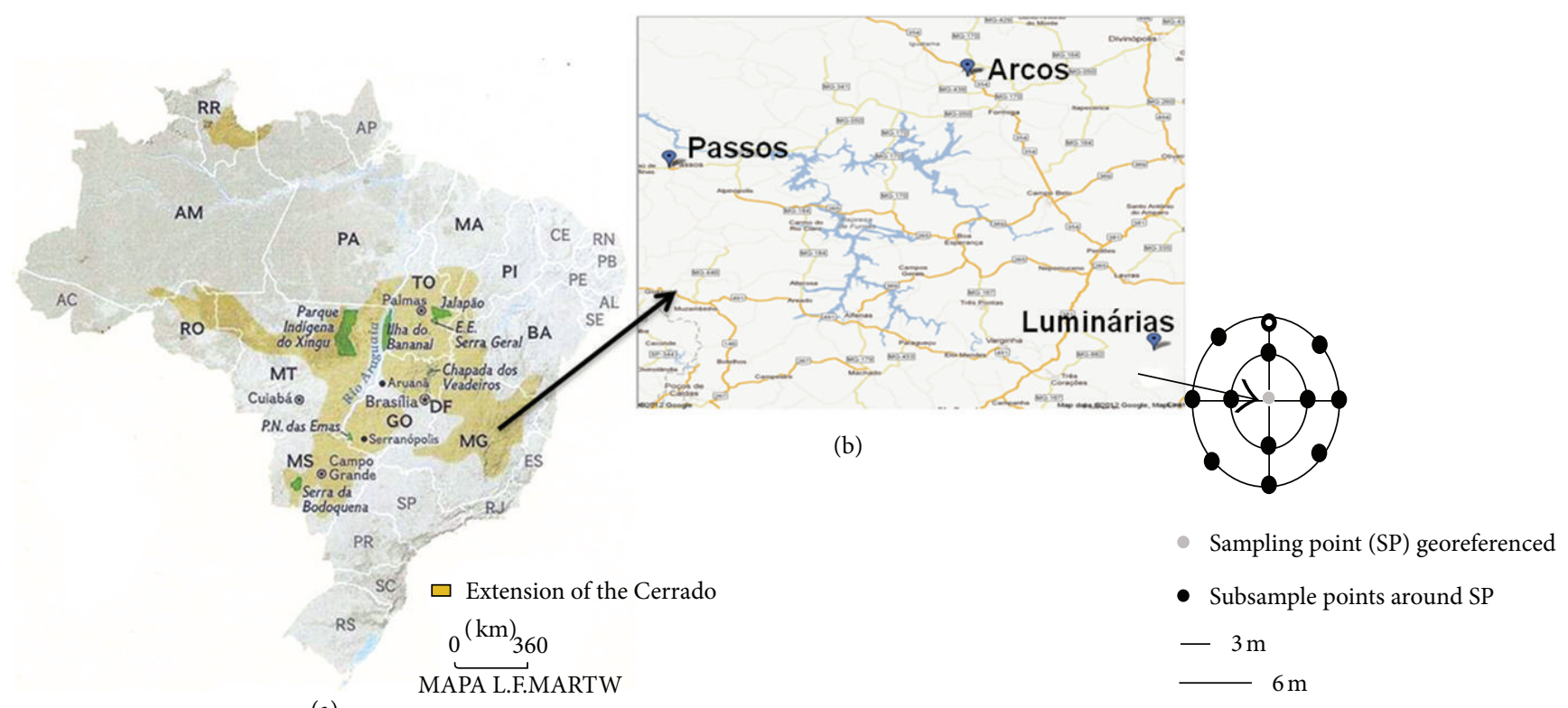

(a)

(c)

FIGURE 1: (a) Location of Cerrado soil in Minas Gerais, Brazil. (b) Cities where samples were collected. (c) Distribution of sampling point. Sampling point scheme: one composed soil sample (12 subsamples) was collected around each sampling point.

explored for the search and discovery of novel Actinobacteria spp. In this study, isolation of Actinobacteria species from Brazilian Cerrado soils and comparisons of the Actinobacteria communities of the Cerrado soil with the physicochemical characteristics of these soils were performed. Some of the isolates that showed promise for use in biotechnology were identified and tested for the production of bioactives (e.g., enzymes and antibiotics).

\section{Materials and Methods}

2.1. Soil Sampling. Thirty composite soil samples were collected during the months of January (rainy season) and August (dry season) from the Passos, Arcos, and Luminárias municipalities. These soils are highly conserved (native), and the locations are georeferenced in Table 1 and Figure 1. Each sample was obtained according to the procedure of Lima et al. [8]. Twelve subsamples of 75 to $100 \mathrm{~g}$ were collected from each point in two concentric circles with radii of 3 and $6 \mathrm{~m}$ from the centre and a depth of 0 to $20 \mathrm{~cm}$ using a flamed auger. The collected material from each point was mixed in a sterile bag and stored at $4^{\circ} \mathrm{C}$ until analysis.

2.2. Physicochemical Analysis of Soils. Approximately $200 \mathrm{~g}$ of each soil sample was subjected to physicochemical analysis using the procedure of the Embrapa [9]. The concentrations of potassium $(\mathrm{K})$, phosphorus $(\mathrm{P})$, aluminium (Al), magnesium $(\mathrm{Mg})$, organic matter $(\mathrm{OM})$, hydrogen and aluminium $(\mathrm{Al}+\mathrm{H})$ and exchangeable bases $(\mathrm{SB})$ as well as the $\mathrm{pH}$ and soil texture were evaluated. The Sisvar 5.1 program of the SAS System 9.1 software (SAS Institute Inc., Cary, NC, USA) was used for statistical analysis of the differences between the means. Correlations between the Brazilian Cerrado soils'
TABle 1: Location and description of the Brazilian Cerrado soil collection sites.

\begin{tabular}{lc}
\hline Site name & Location \\
\hline Region of Passos & $20^{\circ} 49^{\prime} 57.7^{\prime \prime} \mathrm{S} ; 046^{\circ} 30^{\prime} 29.3^{\prime \prime} \mathrm{W}$ \\
Point 1 & $20^{\circ} 49^{\prime} 56.8^{\prime \prime} \mathrm{S} ; 046^{\circ} 30^{\prime} 30.1^{\prime \prime} \mathrm{W}$ \\
Point 2 & $20^{\circ} 49^{\prime} 48.0^{\prime \prime} \mathrm{S} ; 046^{\circ} 30^{\prime} 54.9^{\prime \prime} \mathrm{W}$ \\
Point 3 & $20^{\circ} 49^{\prime} 47.1^{\prime \prime} \mathrm{S} ; 046^{\circ} 30^{\prime} 54.5^{\prime \prime} \mathrm{W}$ \\
Point 4 & $20^{\circ} 49^{\prime} 47.8^{\prime \prime} \mathrm{S} ; 046^{\circ} 30^{\prime} 51.5^{\prime \prime} \mathrm{W}$ \\
Point 5 & \\
Region of Luminárias & $21^{\circ} 37^{\prime} 51.0^{\prime \prime} \mathrm{S} ; 044^{\circ} 58^{\prime} 22.7^{\prime \prime} \mathrm{W}$ \\
Point 6 & $21^{\circ} 37^{\prime} 50.6^{\prime \prime} \mathrm{S} ; 044^{\circ} 58^{\prime} 22.7^{\prime \prime} \mathrm{W}$ \\
Point 7 & $21^{\circ} 37^{\prime} 51.5^{\prime \prime} \mathrm{S} ; 044^{\circ} 59^{\prime} 11.0^{\prime \prime} \mathrm{W}$ \\
Point 8 & $21^{\circ} 37^{\prime} 55.3^{\prime \prime} \mathrm{S} ; 044^{\circ} 59^{\prime} 29.3^{\prime \prime} \mathrm{W}$ \\
Point 9 & $21^{\circ} 37^{\prime} 54.6^{\prime \prime} \mathrm{S} ; 044^{\circ} 59^{\prime} 54.0^{\prime \prime} \mathrm{W}$ \\
Point 10 & \\
Region of Arcos & $20^{\circ} 16^{\prime} 27.7^{\prime \prime} \mathrm{S} ; 045^{\circ} 29^{\prime} 14.6^{\prime \prime} \mathrm{W}$ \\
Point 11 & $20^{\circ} 14^{\prime} 47.9^{\prime \prime} \mathrm{S} ; 045^{\circ} 25^{\prime} 35.9^{\prime \prime} \mathrm{W}$ \\
Point 12 & $20^{\circ} 14^{\prime} 51^{\prime \prime} \mathrm{S} ; 045^{\circ} 31^{\prime} 40.8^{\prime \prime} \mathrm{W}$ \\
Point 13 & $20^{\circ} 14^{\prime} 48.6^{\prime \prime} \mathrm{S} ; 045^{\circ} 31^{\prime} 33.4^{\prime \prime} \mathrm{W}$ \\
Point 14 & $20^{\circ} 14^{\prime} 58.0^{\prime \prime} \mathrm{S} ; 045^{\circ} 31^{\prime} 54.0^{\prime \prime} \mathrm{W}$ \\
Point 15 &
\end{tabular}

regions and the physicochemical soil variables were subjected to statistical analysis (principal component analysis or PCA) using the Unscrambler 9.7 software (CAMO, Oslo, Norway).

2.3. Bacterial Isolation and Culture Purification. Ten grams of soil from each composite sample was added to $90 \mathrm{~mL}$ of sterile peptone water (bacto peptone, $1 \mathrm{~g} / \mathrm{L}$ ) and homogenised by stirring at $130 \mathrm{rpm}$ for $10 \mathrm{~min}$ (dilutions of $10^{-1}$ to $10^{-8}$ ). These 
TABLE 2: Actinobacterial-specific primer used in bacterial communities in the Brazilian Cerrado soils, according to Schäfer et al. [12].

\begin{tabular}{|c|c|c|c|c|}
\hline Primer & Sequence $\left(5^{\prime}-3^{\prime}\right)$ & Primers & $\begin{array}{l}\text { Amplified } \\
\text { fragment (bp) }\end{array}$ & PCR conditions \\
\hline $27 f$ & GAG TTT GAT CMT GGC TCA G & \multirow{2}{*}{ Bacterial universal primer } & \multirow{2}{*}{$\sim 1500$} & \multirow{6}{*}{$\begin{array}{l}\text { Denatured for } 5 \mathrm{~min} \text { at } \\
95^{\circ} \mathrm{C} .30 \text { cycles: denaturing } \\
\text { at } 92^{\circ} \mathrm{C} \text { for } 60 \mathrm{~s} \text {, annealing } \\
\text { at } 55^{\circ} \mathrm{C} \text { for } 60 \mathrm{~s} \text {, and } \\
\text { extension at } 72^{\circ} \mathrm{C} \text { for } 60 \mathrm{~s} \text {; } \\
\text { final extension for } 10 \mathrm{~min} \text { at } \\
72^{\circ} \mathrm{C}\end{array}$} \\
\hline $1492 \mathrm{r}$ & ACG GYT ACC TTG TTA CGA CTT & & & \\
\hline Com $2 x f$ & AAA CTC AAA GGA ATT GAC GG & \multirow{2}{*}{$\begin{array}{l}\text { Actinobacterial-specific } \\
\text { primer }\end{array}$} & \multirow{2}{*}{$\sim 270$} & \\
\hline Ac1186r & CTT CCT CCG AGT TGA CCC & & & \\
\hline SC-Act-235aS20 & CGC GGC CTA TCA GCT TGT TG & \multirow{2}{*}{$\begin{array}{l}\text { Actinobacterial-specific } \\
\text { primer }\end{array}$} & \multirow{2}{*}{$\sim 640$} & \\
\hline SC-Act-878aA19 & CCG TAC TCC CCA GGC GGG G & & & \\
\hline
\end{tabular}

sample dilutions were used for inoculations by spreading $100 \mu \mathrm{L}$ on the surface of Aaronson's medium according to Silva et al. [10] and humic acid vitamin medium according to Hayakawa and Nonomura [11]. The plates were incubated for $72 \mathrm{~h}$ to $120 \mathrm{~h}$ at $28^{\circ} \mathrm{C}$.

From the plates containing 30 to $300 \mathrm{CFU}$, a number of colonies equal to the square root of the number of different quantified of each colonial morphotypes were isolated [13]. These morphotype strains were cultured for 72 to $120 \mathrm{~h}$ at $28^{\circ} \mathrm{C}$ in $500 \mu \mathrm{L}$ of nutrient broth supplemented with glycerol to a final concentration of $20 \%$. The isolates were purified by successive restreak and were preserved by freezing at $-20^{\circ} \mathrm{C}$. The strains were reactivated on nutrient agar by incubating for 72 to $120 \mathrm{~h}$ at $28^{\circ} \mathrm{C}$ and were then characterised for bacterial colony morphology (i.e., size, shape, elevation, brightness, texture and colour) by making comparison between the colonies that were originally isolated from the culture media. The pure cultures were preserved under the conditions described above.

2.4. PCR Primer System for Selective Amplification of Actinobacteria. Pure cultures of the various colonial morphotypes were characterised by actinobacterial-specific primers according to Schäfer et al. [12] and described in Table 2. The $27 \mathrm{f}$ and $1492 \mathrm{r}$ universal bacterial primers were used as controls. The actinobacterial strains were subjected to molecular characterisation by REP-PCR as described below.

2.5. Molecular Characterisation Based on Repetitive Extragenic Palindromic-PCR (Rep-PCR). Total genomic DNA was extracted as described by Pereira et al. [13]. The molecular characterisation of selected isolates was performed by polymerase chain reaction sequencing by REP-PCR as described by Gevers et al. [14]. Two microliters of DNA were added to $12.5 \mu \mathrm{L}$ of Taq PCR Master Mix (Qiagen, São Paulo, Brazil), $8 \mu \mathrm{L} \mathrm{H} \mathrm{H}_{2} \mathrm{O}, 0.25 \mu \mathrm{L}$ bovine serum albumin (BSA), $0.25 \mu \mathrm{L}$ of formamide, and $2 \mu \mathrm{L}$ of primer $\mathrm{GTG}_{5}\left(5^{\prime}\right.$-GTG GTG GTG GTG GTG-3') [13]. PCR was performed under the following cycling conditions: $5 \mathrm{~min}$ initial denaturation at $94^{\circ} \mathrm{C} ; 30$ cycles of $95^{\circ} \mathrm{C}$ for $30 \mathrm{~s}, 45^{\circ} \mathrm{C}$ for $60 \mathrm{~s}$ and $60^{\circ} \mathrm{C}$ for $5 \mathrm{~min}$; and a final elongation at $60^{\circ} \mathrm{C}$ for $16 \mathrm{~min}$. The PCR products were separated by electrophoresis on a $2 \%$ agarose gel in $1 \mathrm{x}$ TAE buffer at $60 \mathrm{~V}$ for $4 \mathrm{~h}$, stained with SYBR Green (Invitrogen, Foster City, CA, USA), and visualised under a transilluminator. The Rep-PCR profiles were subjected to cluster analysis using the Bionumerics 2.50 software (Applied Maths, Sint-Martens-Latem, Belgium).

2.6. PCR Amplification and DNA Sequencing of the $16 S$ rRNA Gene. Representative isolates of each Rep-PCR profile were selected for amplification of the 16S rRNA gene as described by Pereira et al. [13]. DNA $(2 \mu \mathrm{L})$ was added to $30 \mu \mathrm{L}$ of Taq PCR Master Mix (Qiagen, São Paulo, Brazil), $26 \mu \mathrm{L}$ of $\mathrm{H}_{2} \mathrm{O}, 1 \mu \mathrm{L}$ of primer $27 \mathrm{f}$ ( $5^{\prime}$-AGAGTTTGATCCTGGCTCAG- $3^{\prime}$ ), and $1 \mu \mathrm{L}$ of primer 1512r (5'-ACGGCTACCTTGTTACGACT- $\left.3^{\prime}\right)$. The PCR reaction was performed as follows: initial denaturation at $95^{\circ} \mathrm{C}$ for $10 \mathrm{~min} ; 25$ cycles at $93^{\circ} \mathrm{C}$ for $1 \mathrm{~min}, 50^{\circ} \mathrm{C}$ for $1 \mathrm{~min}$, and $72^{\circ} \mathrm{C}$ for $1 \mathrm{~min} 30 \mathrm{~s}$; and a final elongation at $72^{\circ} \mathrm{C}$ for $5 \mathrm{~min}$. The presence of PCR products was confirmed by electrophoresis on a $1 \%$ agarose gel in $1 \mathrm{x}$ TAE buffer at $70 \mathrm{~V}$ for $30 \mathrm{~min}$, stained with SYBR Green (Invitrogen, Foster City, CA, USA), and visualised under a transilluminator. The sequencing of amplicons was performed at Macrogen Inc. (Seoul, South Korea), and the sequences were compared with the GenBank database using the BLAST algorithm (http://www.ncbi.nlm.nih.gov/BLAST/).

\section{Results}

3.1. Physicochemical Characteristics of the Brazilian Cerrado Soil Samples. The chemical and biochemical properties of the Cerrado soil from the Passos, Luminárias, and Arcos regions during the rainy and dry seasons are shown in Table 3. The $\mathrm{pH}$ values of the soils ranged from 4.7 to $5.5,5.0$ to 5.4, and 4.1 to 5.0 for the Passos, Luminárias, and Arcos regions, respectively. These soils had high acidity.

Differences in the soil textures from the Arcos, Passos, and Luminárias regions were observed. The three analysed areas revealed no significant differences in organic matter values. In general, the physical and chemical characteristics for all the soils analysed were similar.

A multivariate analysis using frequency values for the chemical characteristics of the Brazilian Cerrado soils was performed (Figure 2). Samples obtained from the Arcos region were significantly different from the Luminárias and Passos regional samples because of the high concentration of phosphorus during the rainy season and high concentrations of aluminium and potassium during the dry season in the Arcos region. 


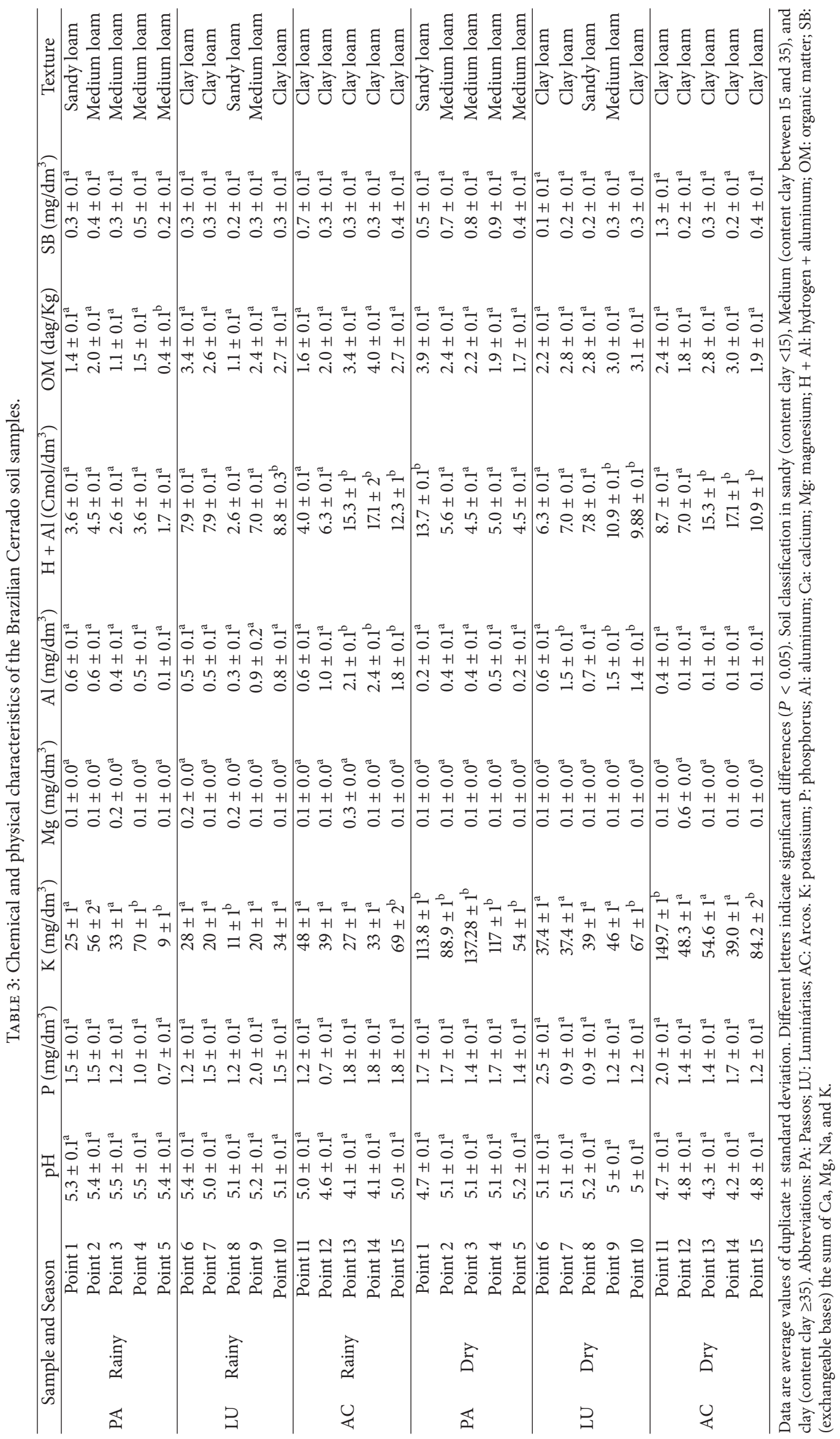




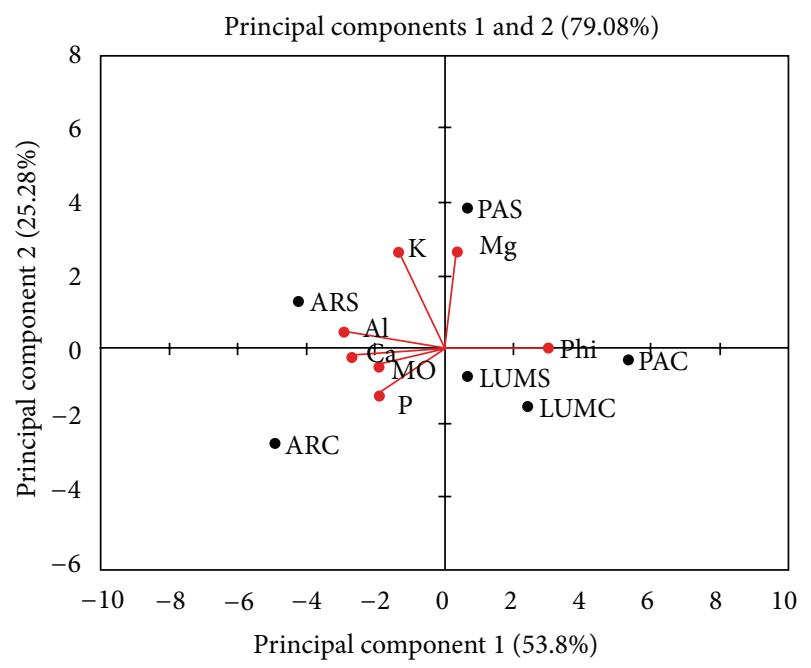

Figure 2: Principal component analysis (PCA) of chemical characteristics of the Brazilian Cerrado soil of Minas Gerais. Abbreviations: $\mathrm{K}$ = potassium; $\mathrm{P}=$ phosphorus; $\mathrm{Al}=$ aluminum, $\mathrm{Ca}=$ calcium, $\mathrm{Mg}$ $=$ magnesium $;$ PAC $=$ Passos $($ rainy season $) ;$ PAS $=$ Passos $($ dry season); $A R C=$ Arcos (rainy season); ARS = Arcos (dry season); LUMC = Luminárias (rainy season); LUMS = Luminárias (dry season).

TABLE 4: Actinobacteria count of the population in $\log$ CFU/g of soil in differents medium during the rainy and dry season.

\begin{tabular}{lcc}
\hline & \multicolumn{2}{c}{$\begin{array}{c}\text { Region } \\
\text { Aaronsons's medium }\end{array}$} \\
& \multicolumn{2}{c}{ Humic acid vitamin medium } \\
\hline Arcos & $7.9 \pm 0.1^{\mathrm{a}}$ & $6.6 \pm 0.1^{\mathrm{b}}$ \\
Luminárias & $7.8 \pm 0.1^{\mathrm{a}}$ & $6.8 \pm 0.1^{\mathrm{b}}$ \\
Passos & $7.8 \pm 0.1^{\mathrm{a}}$ & $6.7 \pm 0.1^{\mathrm{b}}$ \\
\hline \multicolumn{3}{c}{ Rainy season } \\
\hline Arcos & $9.1 \pm 0.2^{\mathrm{c}}$ & $7.2 \pm 0.1^{\mathrm{d}}$ \\
Luminárias & $8.9 \pm 0.2^{\mathrm{c}}$ & $7.1 \pm 0.1^{\mathrm{d}}$ \\
Passos & $8.8 \pm 0.1^{\mathrm{c}}$ & $7.2 \pm 0.2^{\mathrm{d}}$
\end{tabular}

Data are mean values of duplicate \pm standard deviation.

Different letters indicate significant differences $(P<0.05)$.

3.2. Microbial Isolation and Characterisation. Of the culture media tested (Aaronsons's medium and humic acid vitamin medium), all were able to recover colonies from all of the soil samples (Table 4).

Total bacterial counts were compared between the rainy and dry seasons. A statistically significant difference $(P<$ 0.05 ) was observed for all the analysed areas (Table 4$)$. The rainy season exhibited higher microbial counts $(\sim 9.1 \log$ $\mathrm{CFU} / \mathrm{g})$ compared to the dry season $(\sim 7.9 \log \mathrm{CFU} / \mathrm{g})$.

A total of 2152 isolates were characterised. The isolates were selected from the groups and subjected to group analysis corresponding to each region. The selected isolates from each region (188 isolates) were characterised by Rep-PCR, and 78 different band profiles were obtained (Figure 3 ).

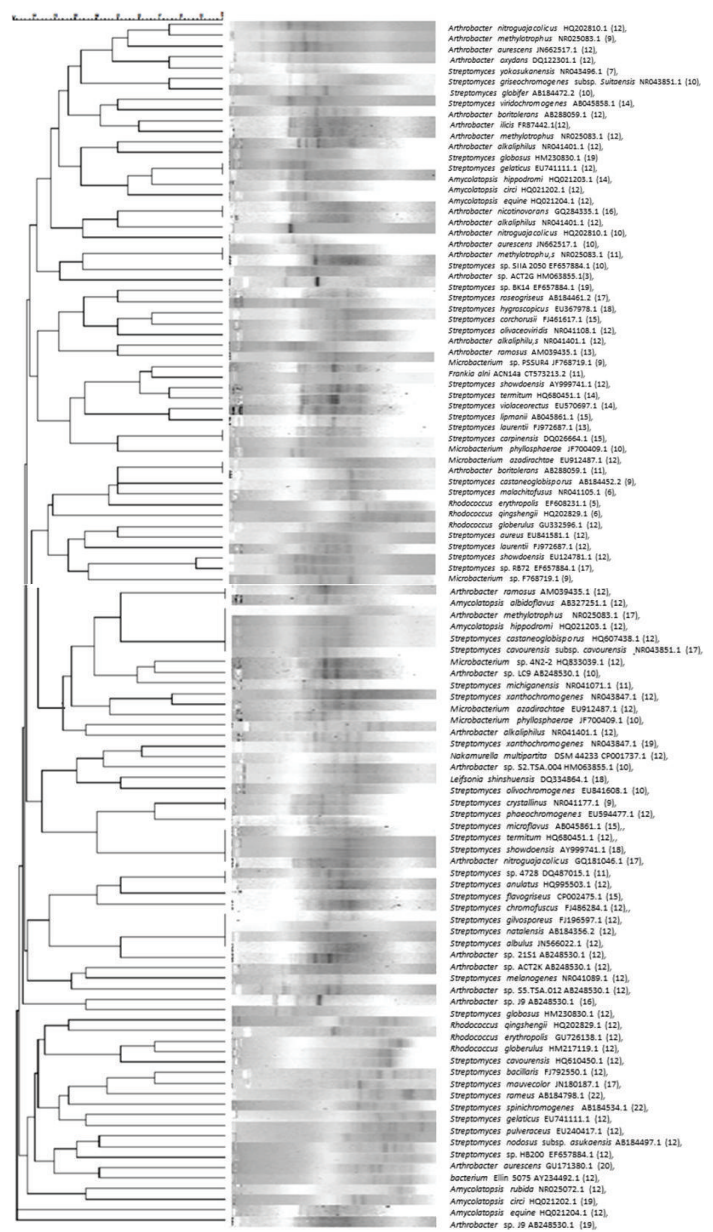

FIGURE 3: Similarity analysis between the bands' profiles (Rep-PCR) of the Actinobacteria isolates of the Brazilian Cerrado soils of three regions: Arcos, Passos, and Luminárias. ( ) OTUs quantification.

3.3. Identification and Distribution of Isolates. The analysis of the $16 \mathrm{~S}$ rRNA gene sequence amplification products led to the identification of nine Actinobacteria genera (Streptomyces, Artrobacter, Rhodococcus, Amycolatopsis, Microbacterium, Frankia, Leifsonia, Nakamurella, and Kitasatospora) and 92 distinct species within the genera (Figure 3 and Table 5).

The genera Streptomyces, Artrobacter, Rhodococcus, Amycolatopsis, and Microbacterium were found in all three regions analysed. Leifsonia, Nakamurella, and Kitasatospora were found only in the Arcos region, and the genus Frankia was not found in the Passos region (Table 5).

The distributions of Actinobacteria genera were different in the Cerrado soils during the rainy and dry seasons (776 isolates were from the dry season, and 1376 isolates were from the rainy season) (Table 5). The rainy season produced a higher microbial population for all described genera (Figure 4).

\section{Discussion}

The Cerrado biome has two distinct seasons: the dry season (May to September) and the rainy season (November to 


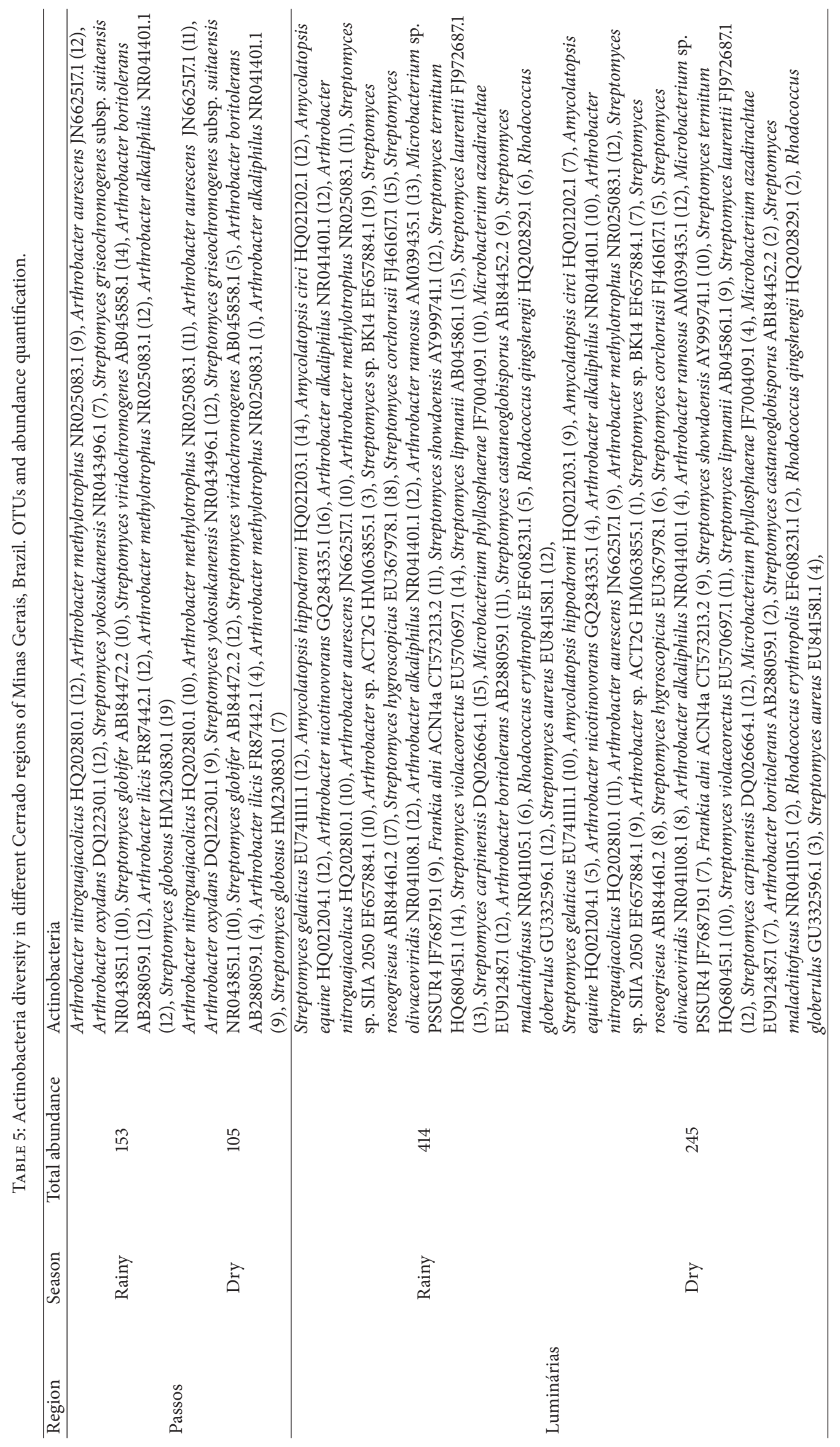




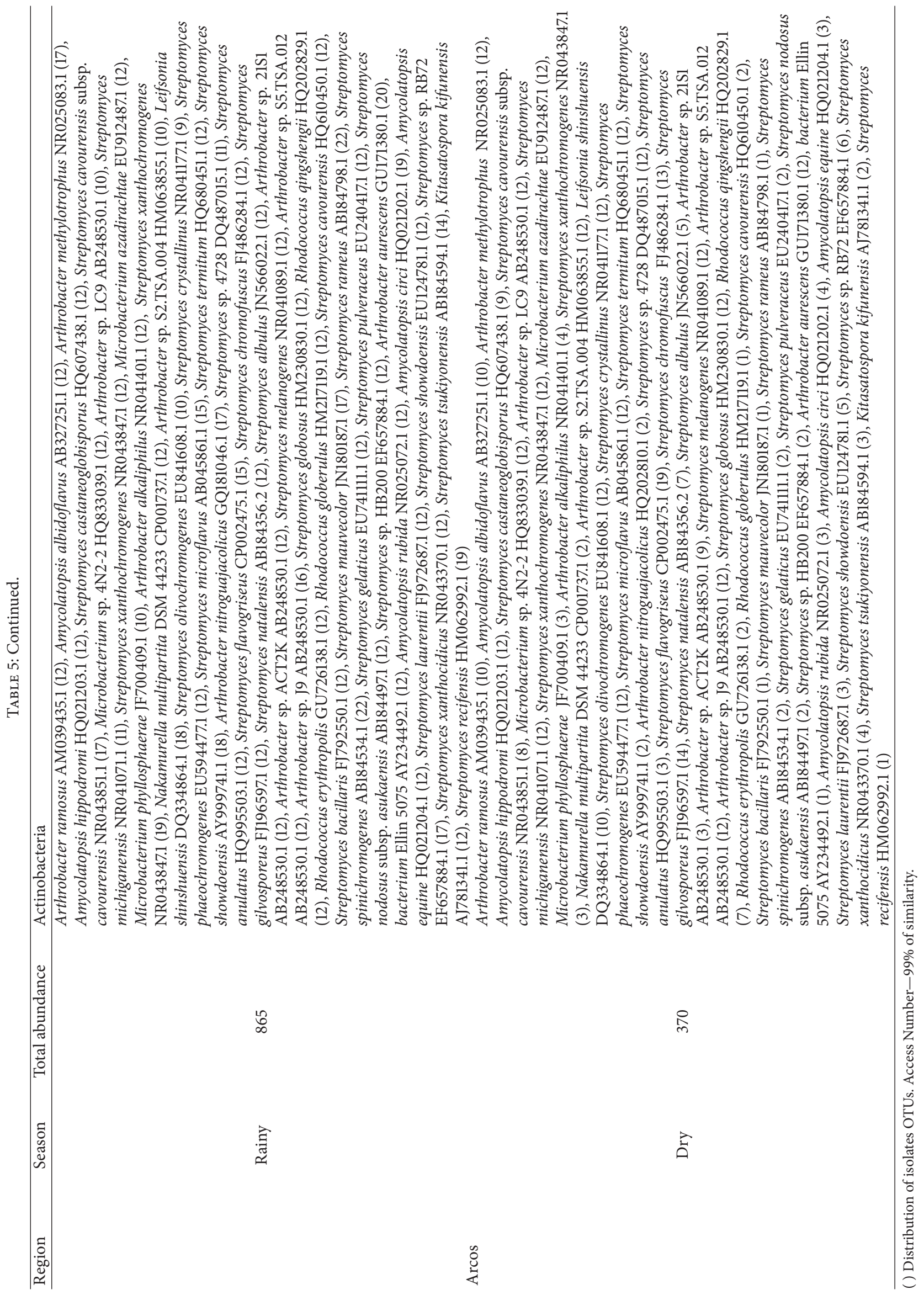



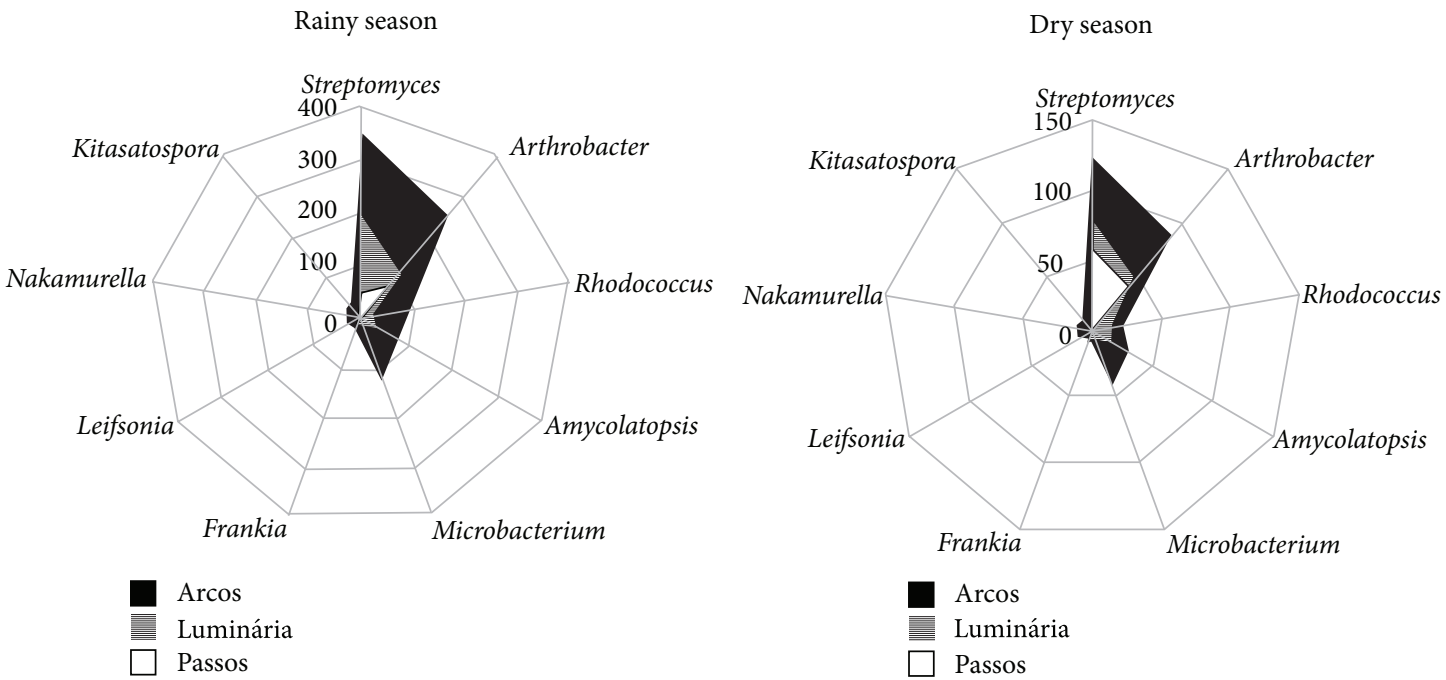

FIGURE 4: Actinobacteria genera abundance distribution in Cerrado soil in the rainy and dry seasons.

April). An important factor relevant to this study is that the soil samples were collected at the peak of each season; thus, the distinction between the samples was maximised because water was either limited or abundant [15]. The samples were collected in January (high rainfall, $1000-2100 \mathrm{~mm}$ ) and August (low rainfall, $20-200 \mathrm{~mm}$ ) of 2010. An important caveat is the heterogeneity of the distribution of microorganisms in the soil because microbial growth is usually observed in patches rather than homogeneously [16-18]. We minimised this potential bias by collecting samples from different spots in each area studied and mixing the individual samples to obtain a composite sample.

Microorganisms are the key drivers of biogeochemical processes in the soil. Thus, it is important to evaluate the physicochemical properties of the soil and how these properties could be related to microbial profiles in different soils [19]. These changes in the soil affect the native microbial populations. Seasonal variations in the moisture and $\mathrm{pH}$ of the soil can lead to changes in the distribution patterns of the microbial species. For example, bacteria prefer neutral to alkaline conditions, whereas yeasts and filamentous fungi prefer acidic conditions. Some microbial species also have preferences for soils with high or low moisture contents [20]. These Cerrado soils had high acidity, consistent with the values found in Cerrado soils that have been reported by studies of others $[15,21]$. The Cerrado soils are commonly acids. This may be due to the vegetative and microbial population present $[15,21]$. Despite having low $\mathrm{pH}$, large amounts of aluminium and iron, and low nutrient content, these soils are extensively used in agriculture. One of the few studies dealing with the Microbiota of these soils reported high numbers of Actinobacteria [21].

The $\mathrm{pH}$ values of the Cerrado soils were similar; however, moisture influenced the total microbial population counts. Samples collected in the rainy season are contained in a higher microbial population $(\sim 9.1 \log \mathrm{CFU} / \mathrm{g})$ than those collected in the dry season $(\sim 7.9 \log$ CFU/g) (Table 4$)$.
The Arcos regional soil contained large amounts of aluminium $\left(\sim 2.4 \mathrm{mg} / \mathrm{dm}^{3}\right)$ during the rainy season and large amounts of hydrogen and aluminium during the rainy and dry seasons $\left(\sim 15 \mathrm{Cmol} / \mathrm{dm}^{3}\right)$ (Table 3$)$. High quantities of soluble aluminium in the soil can cause toxicity in plants, as aluminium competes with other elements (e.g., essential nutrients) for the same chemical sites and promotes soil impoverishment [22]. However, in this study, the Microbiota was not affected by high aluminium levels in the soil based on the similarity of this population to those at the other sampled sites. The three analysed areas (Luminárias, Arcos, and Passos) displayed no significant differences in organic matter contents, which may be due to the similarity in the vegetation and riverbank forest profiles of the three areas [15].

Brazilian Cerrado soils cover a vast area, representing up to $25 \%$ of the country [1]. Despite having a low pH ( 5.0$)$, large amounts of aluminium and iron, and a low nutrient content, these soils are extensively used in agriculture. One of the few studies examining the microbial population of these soils reported on high numbers of Actinobacteria [21]. Huddleston and collaborators [23] found a culturable streptomycete population of approximately $8.0 \log \mathrm{CFU} / \mathrm{g}$ in soil. In the previous study, the number of Actinobacteria isolated from those soils was on the same order of magnitude ( $~ 8.8 \log$ CFU/g of soil) as the number isolated from soils of the Brazilian Cerrado regions of the Minas Gerais State (Luminárias, Passos, and Arcos). These findings suggest that the Cerrado soils represent a large, unexplored environment for the potential isolation of Actinobacteria. Morphological and physiological data led to either a partial or complete identification of 2152 isolates from the Cerrado soil. Dendrograms of the identified strains indicated that they were phenotypically diverse from the Actinobacteria species already described with the majority clustering in a separate and isolated group. Tropical soils present a myriad of microhabitats scarcely explored microbiologically. According to Zucchi et al. [1], of the 16,013 fungal species described 
as new to science over a ten-year period (from 1981 to 1990), $49 \%$ of the species were from tropical countries. This observation may be extended to other microbial groups, including Actinobacteria, for which there are no statistics available concerning Brazilian tropical soils.

Actinobacteria are Gram-positive, morphologically and physiologically very diverse bacteria with a high GC content in their DNA, and they are one of the main phyla within the domain Bacteria. The class Actinobacteria contains six orders-Acidimicrobiales, Rubrobacterales, Coriobacterales, Bifidobacteriales, Actinomycetales, and Nitriliruptorales. Actinobacteria are dominant colonizers in soils. Many species produce extracellular enzymes for degradation of macromolecules such as lignin, cellulose, chitin, and, in part, starch. Therefore, Actinobacteria often occur in materials where organic materials are degraded [12]. In particular, investigations in the indoor environment demonstrated their presence in water-damaged building materials and soils beside fungi [12]. This may explain the high presence of Actinobacteria in these soils of Brazilian Cerrado. In nature, Actinobacteria play an important role in the cycling of organic compounds and have also been associated with soil organic matter production, owing to their black pigments called melanins, which are related, in some respects, to soil humic acid [12, 21].

In the present work, the soils studied were characterised as being especially rich in the Streptomyces genus, as are other soils throughout the world. The Streptomyces genus has been the focus of research because of the commercial applicability of substances produced as well as the systematics of this group, which have been modified with advances in molecular biology [24]. Among the species isolated, S. cavourensis is a producer of the antibiotic chromomycin [25] and $S$. michiganensis is involved in the synthesis of anthelmintic and antiprotozoal substances [26].

Members of the Arthrobacter genus are widely distributed in ecosystems and can be isolated from diverse environments, such as air, water (fresh and salt), soil, oil, airborne infections, tobacco leaves, human skin, and activated sludge. Arthrobacter spp. exhibit great metabolic versatility and are able to degrade pollutants and xenobiotics, such as heavy metals (As, Cd, Cr, Cu, $\mathrm{Hg}, \mathrm{Ni}, \mathrm{Pb}, \mathrm{Se}, \mathrm{V}$, and $\mathrm{Zn}$ ) [27]. One of the species identified in this work, $A$. ramosus, is involved in the synthesis of protease, an enzyme important for the food, pharmaceutical, leather, and detergent industries. A. ramosus is also highly resistant to a variety of heavy metals and may be useful for bioremediation processes [27].

Species of the Microbacterium genus can be isolated from air, soil, water, fungi, plants, and humans. Many Microbacterium spp. play a significant role in human health, industry, agriculture, environment, bioengineering, and biotechnology and have applicability in the production of exopolysaccharide, degradation of oil, degradation of xylan, metal tolerance, production of biosurfactants, degradation of dimethylsulphide, degradation of lactone, and as a growth promoter in plants [28]. Microbacterium phyllosphaerae was found in all three regions examined in this study. In combination with Burkholderia sp. and Candida tropicallis, M. phyllosphaerae performs the processes responsible for the biodegradation of chlorophenols, which are commonly used in the chemical industry as intermediates in the synthesis of insecticide, fungicide, and herbicide and cause serious environmental damage [28].

The strains identified in this study have been previously characterised as important for biotechnology applications. Studies are currently being conducted to produce bioactive compounds from Actinobacteria fermentations on different substrates. The present data suggest that the number and diversity of Actinobacteria in tropical soils represent a vast unexplored resource for the biotechnology of bioactives production.

\section{Future Perspectives}

We commented on the introduction on the global development of soil microbiology and the renaissance taking place in natural product research. Furthermore, we reiterated our belief that natural product search and discovery with soil Actinobacteria shows exceptional promise. Our optimism is based on the spectacular technological armamentarium that is now available as well as the relatively complete but slowly developing understanding of soil biology. This optimism is also encouraged by the wide range of natural products that may exist with a diversity of applications (e.g., enzymes [5], antibiotics [4], fertilizer, pesticide [16], etc.). However, in this study, the focus was on the microbial diversity of Actinobacteria. Soil actinobacterial research and discovery is an important component of natural product research but the development of discoveries to yield products must also be addressed. Although there are encouraging signs that the newer biotechnology companies are focusing on soil organisms, medical necessity as much as business opportunity should ultimately be the driver behind investment in natural product drugs.

\section{Acknowledgments}

The authors would like to thank the Coordenação de Aperfeiçoamento de Pessoal de Nível Superior (CAPES), the Conselho Nacional de Desenvolvimento Científico e Tecnológico $(\mathrm{CNPq})$, and the Fundação de Amparo à pesquisa do Estado de Minas Gerais (FAPEMIG) for financial support and scholarships.

\section{References}

[1] T. D. Zucchi, A. S. Guidolin, and F. L. Cônsoli, "Isolation and characterization of actinobacteria ectosymbionts from Acromyrmex subterraneus brunneus (Hymenoptera, Formicidae)," Microbiological Research, vol. 166, no. 1, pp. 68-76, 2011.

[2] J. G. Holt, N. R. Krieg, P. H. A. Sneath, J. T. Stanley, and S. T. Williams, Bergey's Manual of Determinative Bacteriology, Williams \& Wilkins, Baltimore, Md, USA, 9th edition, 1994.

[3] J. M. Piret and A. L. Demain, "Actinomycetes in biotechnology: an overview," in Actinomycetes in Biotechnology, M. Goodfellow, S. T. Williams, and M. Mordarski, Eds., pp. 461-482, Academic Press, London, UK, 1988.

[4] Y. Okami and K. Hotta, "Search and discovery of new antibiotics," in Actinomycetes in Biotechnology, M. Goodfellow, S. T. 
Williams, and M. Mordarski, Eds., pp. 37-67, Academic Press, London, UK, 1988.

[5] W. Peczynska-Czoch and M. Mordarski, "Actinomycetes enzymes," in Actinomycetes in Biotechnology, M. Goodfellow, S. T. Williams, and M. Mordarski, Eds., pp. 219-284, Academic Press, London, UK, 1988.

[6] R. C. Gomes, A. S. Mangrich, R. R. R. Coelho, and L. F. Linhares, "Elemental, functional group and infrared spectroscopic analysis of actinomycete melanins from Brazilian soils," Biology and Fertility of Soils, vol. 21, no. 1-2, pp. 84-88, 1996.

[7] A. Schatz, E. Bugle, and S. A. Waksman, "Streptomycin, a substance exhibiting antibiotic activity against Gram-positive and Gram-negative bacteria," Experimental Biology and Medicine, vol. 55, no. 1, pp. 66-69, 1944.

[8] A. S. Lima, R. S. A. Nóbrega, A. Barberi, K. Da Silva, D. F. Ferreira, and F. M. D. S. Moreira, "Nitrogen-fixing bacteria communities occurring in soils under different uses in the Western Amazon Region as indicated by nodulation of siratro (Macroptilium atropurpureum)," Plant and Soil, vol. 319, no. 1-2, pp. 127-145, 2009.

[9] Embrapa: Empresa Brasileira de Pesquisa Agropecuária, Manual de Métodos de Análise de Solo, Rio de Janeiro, Brazil, 2nd edition, 1997.

[10] C. F. Silva, R. S. Azevedo, C. Braga, R. Silva, E. S. Dias, and R. F. Schwan, "Microbial diversity in a bagasse-based compost prepared for the production of Agaricus brasiliensis," Brazilian Journal of Microbiology, vol. 40, no. 3, pp. 590-600, 2009.

[11] M. Hayakawa and H. Nonomura, "Humic acid-vitamin agar, a new medium for the selective isolation of soil actinomycetes," Journal of Fermentation Technology, vol. 65, no. 5, p. 501, 1987.

[12] J. Schäfer, U. Jäckel, and P. Kämpfer, "Development of a new PCR primer system for selective amplification of Actinobacteria," FEMS Microbiology Letters, vol. 311, no. 2, pp. 103-112, 2010.

[13] G. V. M. Pereira, K. T. Magalhães, E. R. Lorenzetii, T. P. Souza, and R. F. Schwan, "A multiphasic approach for the identification of endophytic bacterial in strawberry fruit and their potential for plant growth promotion," Microbial Ecology, vol. 63, no. 2, pp. 405-417, 2012.

[14] D. Gevers, G. Huys, and J. Swings, "Applicability of rep-PCR fingerprinting for identification of Lactobacillus species," FEMS Microbiology Letters, vol. 205, no. 1, pp. 31-36, 2001.

[15] A. P. Castro, B. F. Quirino, G. Pappas Jr., A. S. Kurokawa, E. L. Neto, and R. H. Krüger, "Diversity of soil fungal communities of Cerrado and its closely surrounding agriculture fields," Archives of Microbiology, vol. 190, no. 2, pp. 129-139, 2008.

[16] M. S. Girvan, J. Bullimore, A. S. Ball, J. N. Pretty, and A. M. Osborn, "Responses of active bacterial and fungal communities in soils under winter wheat to different fertilizer and pesticide regimens," Applied and Environmental Microbiology, vol. 70, no. 5, pp. 2692-2701, 2004.

[17] K. Schwarzenbach, J. Enkerli, and F. Widmer, "Objective criteria to assess representativity of soil fungal community profiles," Journal of Microbiological Methods, vol. 68, no. 2, pp. 358-366, 2007.

[18] B. E. Wolfe, D. L. Mummey, M. C. Rillig, and J. N. Klironomos, "Small-scale spatial heterogeneity of arbuscular mycorrhizal fungal abundance and community composition in a wetland plant community," Mycorrhiza, vol. 17, no. 3, pp. 175-183, 2007.

[19] R. S. Peixoto, G. M. Chaer, N. Franco, F. B. Reis Jr., I. C. Mendes, and A. S. Rosado, "A decade of land use contributes to changes in the chemistry, biochemistry and bacterial community structures of soils in the Cerrado," Antonie van Leeuwenhoek, vol. 98, no. 3, pp. 403-413, 2010.

[20] J. D. Bresolin, M. M. C. Bustamante, R. H. Krüger, M. R. S. S. Silva, and K. S. Perez, "Structure and composition of bacterial and fungal community in soil under soybean monoculture in the Brazilian Cerrado," Brazilian Journal of Microbiology, vol. 41, no. 2, pp. 391-403, 2010.

[21] R. R. R. Coelho and A. Drozdowicz, "The occurrence of actinomycetes in a Cerrado soil in Brazil," Revue d'Ecologie et de Biologie du Sol, vol. 15, pp. 459-473, 1978.

[22] P. G. C. Ruggiero, M. A. Batalha, V. R. Pivello, and S. T. Meirelles, "Soil-vegetation relationships in cerrado (Brazilian savanna) and semideciduous forest, Southeastern Brazil," Plant Ecology, vol. 160, no. 1, pp. 1-16, 2002.

[23] A. S. Huddleston, N. Cresswell, M. C. P. Neves et al., "Molecular detection of streptomycin-producing streptomycetes in Brazilian soils," Applied and Environmental Microbiology, vol. 63, no. 4, pp. 1288-1297, 1997.

[24] R. F. Souza, R. R. R. Coelho, A. Macrae et al., "Streptomyces lunalinharesii sp. nov., a chitinolytic streptomycete isolated from cerrado soil in Brazil," International Journal of Systematic and Evolutionary Microbiology, vol. 58, no. 12, pp. 2774-2778, 2008.

[25] J. D. Skarbek and L. R. Brady, "Streptomyces cavourensis sp. nov. (nom. rev.) and Streptomyces cavourensis subsp. washingtonensis subsp. nov., a Chromomycin-Producing Subspecies," International Journal of Systematic Bacteriology, vol. 28, no. 1, pp. 45-53, 1978.

[26] G. Cassinelli, E. Cotta, G. D’Amico et al., "Thaimycins, new anthelmintic and antiprotozoal antibiotics produced by Streptomyces michiganensis var. amylolyticus var. nova," Archiv für Mikrobiologie, vol. 70, no. 3, pp. 197-210, 1970.

[27] A. Bafana, K. Krishnamurthi, M. Patil, and T. Chakrabarti, "Heavy metal resistance in Arthrobacter ramosus strain G2 isolated from mercuric salt-contaminated soil," Journal of Hazardous Materials, vol. 177, no. 1-3, pp. 481-486, 2010.

[28] L. Lin, W. Guo, Y. Xing et al., "The actinobacterium Microbacterium sp. $16 \mathrm{SH}$ accepts $\mathrm{pBBR} 1$-based $\mathrm{pPROBE}$ vectors, forms biofilms, invades roots, and fixes N2 associated with micropropagated sugarcane plants," Applied Microbiology and Biotechnology, vol. 93, no. 3, pp. 1185-1195, 2012. 

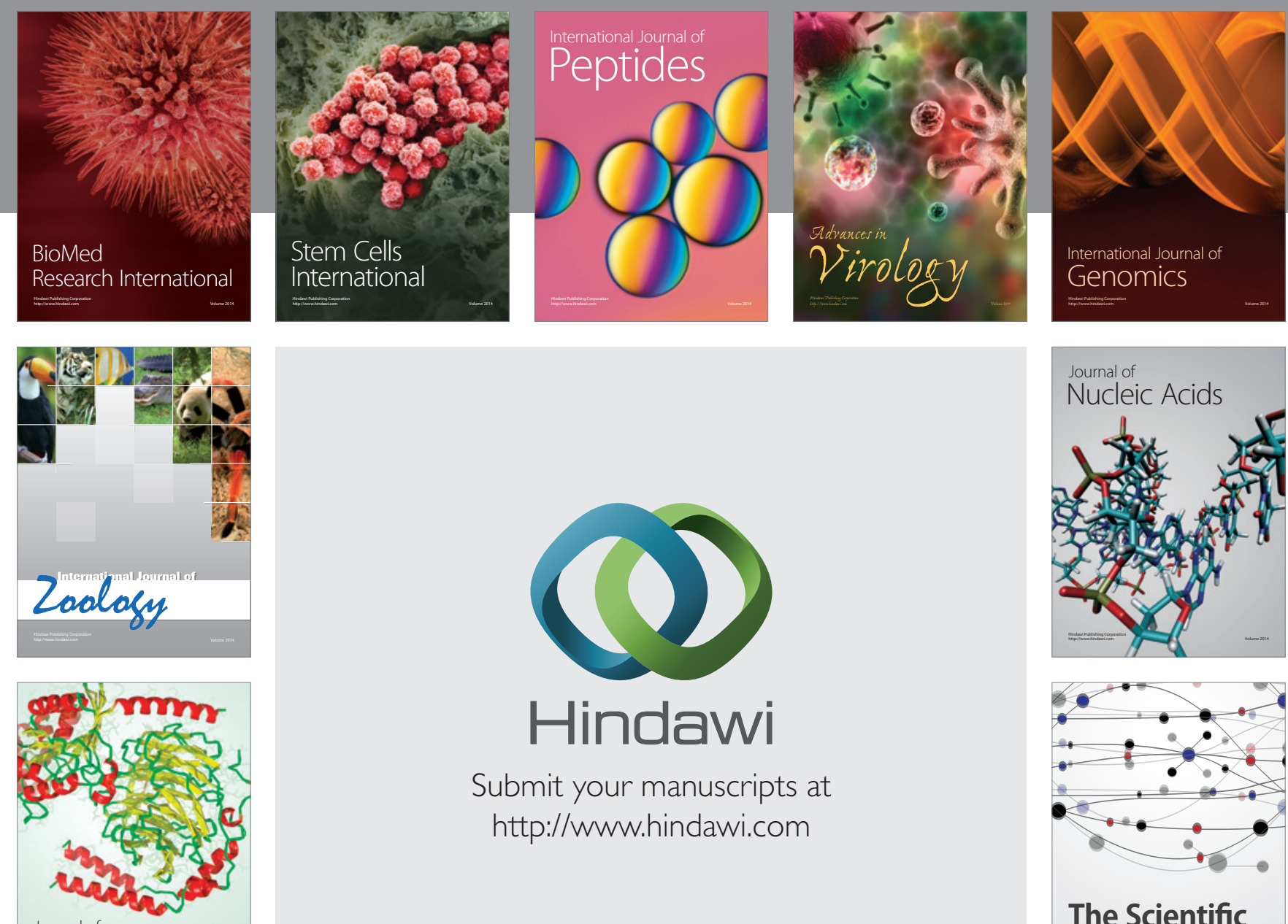

Submit your manuscripts at

http://www.hindawi.com

Journal of
Signal Transduction
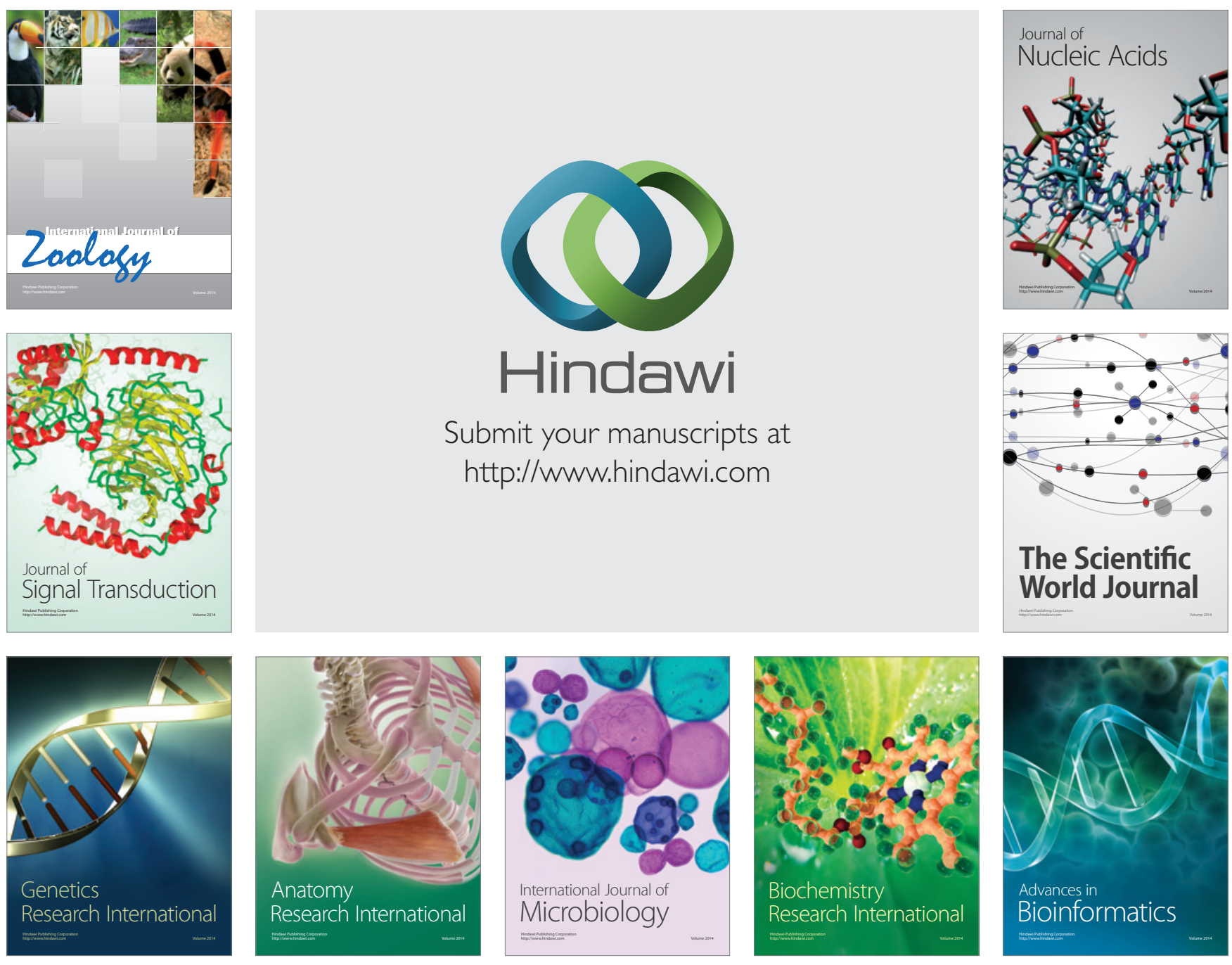

The Scientific World Journal
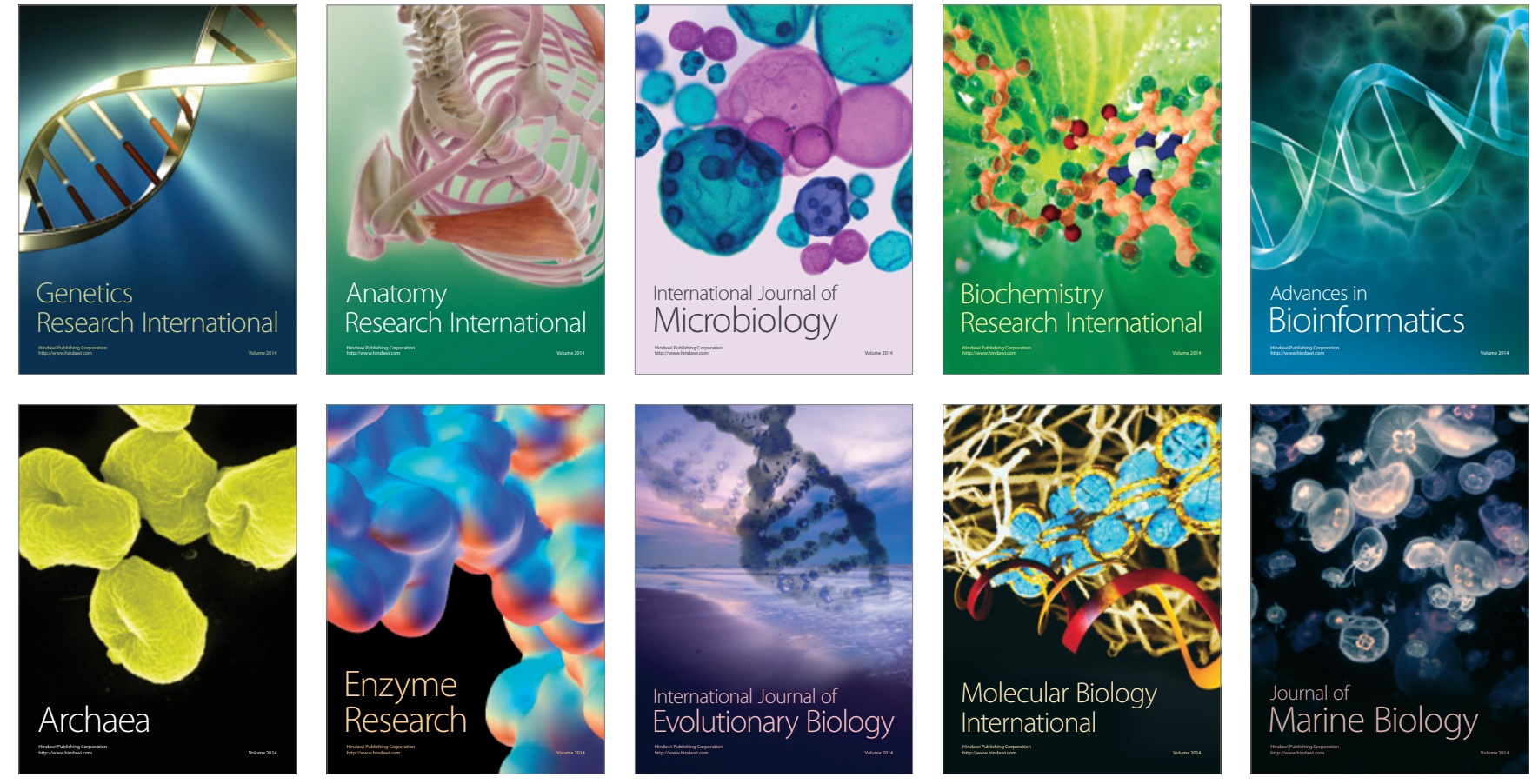